\title{
Scientific networks, Vesuvius and politics The case of Teodoro Monticelli in Naples, 1790-1845
}

\section{John Brewer}

In the Spring of 1820 the British chemist Humphry Davy wrote from Rome to thank his friend the Abate and Cavaliere Teodoro Monticelli for his hospitality during a recent sojourn in Naples, concluding his letter by remarking that 'the things that you have done for me, and the things we did together I will never forget'. ${ }^{1}$ Davy and Monticelli had been working for some months on the slopes of Vesuvius, in 'votre grande et belle laboratoire'2 as Davy put it, and in Monticelli's house, investigating the chemical properties of the mephitic gases and crystals produced by the volcano. Davy's presence in Naples was officially linked to the task, given him by the Prince Regent, of finding a way to unroll the carbonized scrolls from Herculaneum which scholars hoped would reveal unknown works of classical literature. But he was far happier - and more successful - in exploring the volcano with his friend.

Humphry Davy is hardly unknown in the annals of science, but few, even among those who study the history of geology or volcanology, will have heard of Teodoro Monticelli. Yet Monticelli was a powerful figure in his day as well as typical of the many Italian savants, mineralogists and geologists whose work and focus was as much local as international, or perhaps more accurately, who used the international to further local ends. Like many such figures he stood at the intersection of a large body of local knowledge and the greater scientific community, and, like some of his colleagues, he used the promotion of such connections to further a much larger political project, one that looked towards the establishment of constitutional regimes with an educated and enfranchised public, and even on occasion towards an entire peninsula united in a single nation. Monticelli belonged to three different but overlapping networks. One connected Italian savants of mineralogy and geology in Sicily, Naples, Rome, the Tuscan cities, and the towns of northern Italy and the Veneto: Milan, Turin, Bologna, Pavia, Padua. Like-minded, similarly positioned savants were connected through correspondence, exchange of specimens and shared international visitors. Their relations with the travellers was one way in which they were part of a second network that made up a larger scientific community whose centres were, above all, Paris, but also Berlin and London, and which was sustained by correspondence, travel and intellectual and gift exchange. A third, related but rather different in character, consisted of a generation of Italian administrators and functionaries, nurtured first on French revolutionary ideals and then on the views of the French ideologues and Napoleonic functionaries, who were united in a desire for comprehensive reform in which the sciences - not just "natural", but medical, social and political - would

\footnotetext{
${ }^{1}$ Humphry Davy to Teodoro Monticelli, Rome, 7 March 1820, Davy Letters Project (Hereafter DLP), Royal Institution, www.davy-letters.org.uk (accessed 20 June 2018).

2 DLP, Davy to Monticelli, 21 February 1816.
} 
achieve a universal salubriousness. Monticelli used the prestige acquired as a vital intermediary in the first two networks not only for self-advancement (and protection) but to promote the aims of the third network for scientific reform. Vesuvius was vital to this, providing him with the social and cultural capital to pursue his cause.

The volcano and the Bay of Naples gave Monticelli certain advantages. No site was so spectacular - so sublime - and yet so accessible to the savant and the tourist. In Sicily, the Gemmellaro family presided over Etna, a far more impressive mountain, but it was both more inaccessible and much harder to climb. Savants from throughout Italy and in much of Europe and North America constantly solicited lavas, minerals and fossils from the volcano, and pressed Monticelli to send them accounts of Vesuvius and its eruptions; it is clear that they believed that such articles would increase the visibility of their journals. The savants of the other Italian cities had nothing comparable to offer - no regular eruptions, no vast trove of brilliant crystals and rocks, and (with the exception of Rome) no archaeological remains comparable to those of the buried cities. He was primus inter pares.

Monticelli's correspondence was voluminous and survives in the National Library in Naples. Its richness enables us to reconstruct the formation and activities of Italian and European networks of savants, geologists and mineralogists. Much distinguished writing on Italian science in general, and on earth sciences in particular, has focused either on the achievements of particular individuals or the formation of institutional arrangements - notably the national meetings of Italian scientists begun in 1839 in Pisa. ${ }^{3}$ The approach adopted here is different. Though my focus is on Monticelli and Neapolitan science, I reconstruct his networks in order to understand how the study of the earth worked as a set of practices and activities in the first half of the nineteenth century. In doing so I deliberately neglect the whiggish question, that has preoccupied many scholars, about the position of Italian science in relation to the scientific achievements of other countries (one cannot, of course, say nations.) The focus is on how savants worked rather than on what they achieved.

But let me begin with Monticelli himself. Teodoro Monticelli was born in 1759, the younger son of minor nobility from Brindisi, who, like many a younger son who did not go into the military, entered the church. In Brindisi, Lecce, Naples and Rome he was educated in philosophy and mathematics, and was taught by the followers of Antonio Genovesi, who held the first chair in Political Economy in Europe, established in Naples in 1754. He became a radical Jacobin and freemason in the 1790 s, a member of the Società patriottica napoletana, linked to the private studio of the defrocked priest, Carlo Lauberg, who taught applied mathematics and chemistry for revolutionary ends. Arrested in 1794, he was then released - it was clear he was an ardent Jacobin, but not that he was an active conspirator - but then re-arrested in 1795, when he was offered a bishopric if he would betray his fellow radicals. Refusing to do so, he spent the next six years first in the Castel Sant'Elmo high above the city (and in a windowless cell) and then as a prisoner on the remote island of Favignana off the north-west coast of Sicily, where he had been sentenced to ten years of confinement. His incarceration probably saved his life: he was not able to be a part of the brief government of the Neapolitan republic set up by the French in 1799, and radically purged by the Bourbons and Horatio Nelson. Freed in 1801 as part of the amnesty negotiated at the Treaty of Florence, he returned to study and work first in Rome (where he first became

\footnotetext{
3 See for example L. Cerruti, 'Dante's Bones: geography and history of Italian science, 1748-1870', in K. Gavroglu (ed.), Sciences in the European Periphery during the Enlightenment, Dordrecht, Kluwer, 1999, pp. 95-178; G.B. Vai, 'Light and Shadow: the status of Italian geology around 1807', in: Geological Society, London, Special Publications, 317 (2009), pp. 179-202. A contemporary overview can be found in L. Pilla, 'Sui progressi della Orittognosia e della Geognosia in Italia', in: Il Progresso delle Scienze, delle Lettere, e delle Arti, 2 (1832), pp. 37-81, 3 (1832), pp. 165-234.
} 
interested in geology), and then returned to Naples as Professor of Ethics in 1806. With the (second) French occupation of Naples his fortunes flourished, and in 1807 he was made head of the Collegio del Salvatore and a member of the Ministry of Education. In the following year he became permanent Secretary of the Academy of Sciences, was given the title of Cavaliere, and was appointed to the Internal Commission of general Statistics for the Kingdom, responsible for agriculture. ${ }^{4}$

Monticelli's early work had been on husbandry - he had written a catechism for small-holding farmers, a treatise on bee-keeping while on Favignana, and an environmental study, Sull'economia delle acque da ristabilirsi nel regno di Napoli ('On the restoration/recuperation of the economy of water in the Kingdom of Naples') which some modern scholars see as an early work of Italian environmentalism. As we will see, Monticelli never lost interest in these questions, but from 1808 onwards he published a succession of geological works, including an innovative account of the massive 1822 eruption of Vesuvius, and with a chemist, Nicola Covelli, the Prodromo di Vesuvio, a comprehensive analysis of its rocks and minerals. In these papers he and his colleague measured the fallout of pyroclastic deposits, developed an historical classification of volcanic types, and disagreed with the likes of Alexander von Humboldt and von Buch over whether volcanoes were the product of processes of elevation rather than eruption. Described by the Duke of Buckingham when in Naples as 'the great naturalist here', and by Alexander von Humboldt as 'the learned and zealous observer of the Volcano', his achievements as a vulcanist were compared by Humphry Davy to those of Horace Benedict de Saussure as a scholar of the Alps. ${ }^{5}$ Praise from such savants helped Monticelli establish himself as a key figure in the scholarly and public reception of Vesuvius.

Indeed it may well have been for this reason that Monticelli was able to keep his position, despite the change of regimes. The volcano and his association with it protected him. The intervention of the Austrians had prevented the Bourbons from purging the Muratist administration to which he belonged in 1815, but after the failure of the 1820 constitutionalist revolt in Naples Monticelli avoided the fate of many of his long-standing friends who were dismissed or forced into exile. The ardent Jacobin had turned into a pragmatist, willing to accept the Restored dynasty because his positions gave him influence and power. For the last thirty years of his life he was Secretary both of the Società Reale Borbonica, and secretary of one of the three academies that made up that body, L'Accademia delle scienze. His offices made him the public face of both institutions, the chief correspondent with other academies, libraries and museums both within the Italian peninsula and in Europe and the Americas. In 1845, on the last day of the meeting of Italian scientists held at the newly opened Observatory on the slopes of Vesuvius (a project he had ardently promoted but whose inauguration he had been too ill to attend) Monticelli died in his eighty-sixth year. His funeral in Naples was attended by many of the congress's participants. Posthumous panegyrics are rarely reliable, but they seem to have agreed on his 'serene affability', and his 'aura of modesty'. ${ }^{6}$

\footnotetext{
${ }^{4}$ On Monticelli's life see F.P. De Ceglia, 'Monticelli, Teodoro', Dizionario Biografico degli italiani, 76 (2012), http://www.treccani.it/enciclopedia/teodoro-monticelli_Dizionario-Biografico) (accessed 1 June 2018); A. Nazzaro \& A. di Gregorio, 'The Contribution of the Neapolitan Geologist, Teodoro Monticelli $(1759-1845)$ to the development of Geology', in: N. Morello (ed.), Volcanoes and History, Proceedings of the 20 $0^{\text {th }}$ INHIGEO Symposium, 19-25 September 1995, Genoa, Brigati, 1998, pp. 415-433; G. Foscari, Teodoro Monticelli e l'Economia delle acque nel Mezzogiorno moderno, Salerno, Edisud Salerno, 2009, pp. 59-88.

${ }^{5}$ The Private Diary of Richard, Duke of Buckingham and Chandos, London, Hurst and Blackett, 1862, vol. I, p. 314; DLP, Davy to Monticelli, Rome, 8 April 1820.

${ }^{6}$ Mazzarella, 'Della Vita e delle Opere di Teodoro Monticelli', Giornale Euganeo di Scienze, Lettere ed Arti, 2, 3 (1846), p. 495.
} 
Though Monticelli became an assiduous volcanologist, his horizon was bounded by the Kingdom of Naples, and was largely confined to Vesuvius and the Campi Phlegrei. He seems never to have travelled outside the Italian peninsula. Unlike most of the important geologists of his generation, he never crossed the Mediterranean into Greece, the Holy Land and Egypt, nor did he make it northwards over the Alps to France and Germany. His concerns were local and his observations were not theoretical but resolutely empirical. As he and Covelli wrote about the eruption of 1822:

We consulted the ancient and modern writers about our volcanoes and the papers of foreign people on the same topics, as well as the most famous authors of Geology and Mineralogy; however having found that geologists are divided into two tendencies, one of which ascribed most external and internal terrestrial phenomena only to waters, and the other one only to fire, we simply tried to study their doctrines, without embracing any one of them; we only intended to give exact reports of things observed by us. ${ }^{7}$

To a certain extent this was a characteristic gesture of many geologists of the $1820 \mathrm{~s}$ who wished to privilege empirical observation over speculative theory. But it is also probable that Monticelli took this position because his prime concern was less to adjudicate between Neptunists and Plutonists than to ensure that, whatever the larger geological narrative, Vesuvius and the Neapolitan kingdoms would feature within it. For, passionate as Monticelli was about mineralogy, geology and volcanism, his first commitment was to realizing a particular vision of Naples.

Monticelli was determined to insert Vesuvius (both materially and intellectually) into the international geological narrative, because he saw international interest in the volcano as a means to promote Naples as part of a modern, scientific world. He wanted this perception to be both local and international. This involved several interconnected stratagems: acting as a fixer between the volcano, the local scientific community and foreign visitors to Naples; bringing Vesuvius to the attention of a local and international public through the display of collections, accounts of Vesuvius's activity, and the international circulation of specimens; and finally, protecting and ensuring the status of Vesuvius as a scientific object in the face of criticism and hostility from the local Church and other conservative forces.

Let's look at Monticelli's stratagems. Almost every important geologist and major public figure who came to Naples between 1808 and 1840 met Monticelli, who frequently accompanied them on an ascent of Vesuvius. His surviving correspondence is littered with letters of introduction from geologists like Alexander von Humboldt and Humphry Davy recommending savants from Britain, Germany, France, Scandinavia and the New World. In his dealings with this international clientele, Monticelli was a master of the small significant gesture: at Christmas 1814 he entertained Sir William Gell, who became the greatest English-language expert on Pompeii, at his country house at Bosco Tre Case on the southern slopes of Vesuvius, and took the Englishman on his very first visit to the ruins; ${ }^{8}$ he helped Davy on his first visit to Vesuvius in 1814-1815, sent him compounds to Rome for his experiments en route to Naples in 1819, and managed all his affairs during the eruption of $1819-1820 ;{ }^{9}$ when an ill-equipped Humboldt arrived in Naples in 1822, from a diplomatic mission in Verona, Monticelli lent him instruments and log tables to pursue his work. ${ }^{10}$ When Charles Lyell arrived in 1828, two years before the publication of his path-breaking Principles of Geology, he was unable to observe all of Vesuvius, because of its eruptive state, so Monticelli provided him with

\footnotetext{
7 Quoted in Nazzaro \& di Gregorio, 'The Contribution of the Neapolitan Geologist', cit., pp. 426-427.

8 W. Gell, 'Journal 9 August 1814-31 May 1815', Beinecke Library, Yale University, Osborn d293 f.83.

${ }^{9}$ LHD Davy to Monticelli, n.d.; 19 November, 15 December 1818; 21 March, 4 April, 17, 24 October 1819.

${ }^{10}$ Biblioteca Nazionale (hereafter B.N.), Naples, Monticelli Mss, Humboldt to Monticelli, 1822 H.62.
} 
drawings of the parts of the volcano he could not see. ${ }^{11}$ He made travel arrangements for William Buckland and his wife in 1826, and made a life-long friend of the Danish archaeologist Charles Jurgensen-Thomsen, by providing him with accommodation during his visit to Naples in the 1820s. ${ }^{12}$

Monticelli helped not just geologists, but scientists of every stripe, agronomists, botanists, physicists and chemists, doctors and philosophers, cartographers and geographers, mathematicians and statisticians, and the many amateurs and polymaths who were typical of the scientific culture of the period. When the Duke of Buckingham, an ardent amateur geologist, arrived in Naples in the spring of 1828, Monticelli offered the services of his secretary as a guide to the volcanic islands that the Duke was eager to visit in his custom-built (and unpaid for) yacht. Buckingham was delighted with Emmanuele Donati's services - Donati found and identified specimens, supervised an archaeological dig, and, whether on Capri or in Corsica, worked tirelessly on the Duke's behalf. When the two men parted in Genoa, Buckingham gave Donati ten pounds for travel expenses and a gold snuff box, and arranged to pay him fifty pounds. 'He is sorry to go', the Duke wrote, 'and I am equally sorry to lose him, as he has been a very active, quiet, unassuming companion, and has been of great use to me'. ${ }^{13}$

Monticelli also drew visitors into the scholarly life of Naples. He persuaded Charles Babbage, in Italy to recuperate from the loss of his father, wife and son, to sit on a commission - to which the Catalan geologist, Carlos de Gimbernat also contributed - into the curative powers of the waters of Ischia. ${ }^{14} \mathrm{He}$ had the chemist and botanist, Charles Daubeny, author of A Description of Active and Extinct Volcanoes (1826), speak about his researches to the Royal Academy of Science. He even persuaded a rather nervous Christian, Crown Prince of Denmark, an amateur obsessed with geology, to present his findings about Vesuvius to a special session of the Academy. Brokering such events gave the academy greater kudos in the eyes of the court, even as it enhanced its reputation among the foreign visitors and dignitaries who were drawn into its affairs.

A central feature of Monticelli's hospitality was a visit to his collection of Vesuvian lavas and minerals. On 25 January 1820, for example, Christian, Crown Prince of Denmark, visited Monticelli's collection with Humphry Davy, describing it as 'unique' for 'objets volcaniques'; he was also struck by its collection of fossils from Northern Europe which he thought much richer than was usually found in Italy. Originally housed in Monticelli's home, the Museum moved to the Palazzo Penne in the centre of Naples in 1825, and at his death contained 6600 specimens from Vesuvius and a further 1400 minerals from other volcanoes in the Azores, Sardinia and Iceland. This was an entirely separate collection from the royal cabinet of minerals, which had its own curator. Like many others, Christian was fascinated by the collection, which included many volcanic substances that he could not recognize or name. As was often the case, this visit prompted a request that Monticelli put together a collection of 'the most interesting specimens' for the visitor. ${ }^{15}$ As the Duke of Buckingham, another passionate aristocratic collector, commented, 'the collection of Vesuvian minerals is

\footnotetext{
${ }^{11}$ C. Lyell, Principles of Geology; or the modern changes of the earth and its inhabitants, New York, Appleton and Co, 1853, p. 379.

12 B.N., Naples, Monticelli Mss. B.108 Buckland to Monticelli, n.d.; LHD Davy to Monticelli, 20 February 1826; B.N. Monticelli Mss, T. 07, Charles Jurgensen-Thomsen, 13 September 1824.

13 Private Diary of the Duke of Buckingham and Chandos, II, p. 31, 38, 49, 236.

${ }^{14}$ C. Babbage, Passages from the Life of a Philosopher, Martin-Campbell-Kelly (ed.), New Brunswick, Rutgers University Press, 1994, p. 165.

${ }^{15}$ A. Fabritius, F. Friis \& E. Kornerup (eds.), Kong Christian VIIl's dagbøger og Optegnelser. I halvbind 1815-1821, Copenhagen, Udgivet af Det kongelige danske Selskab for Fædrelandets Historie, 1973, 25 January 1820, pp. 204-205.
} 
immense and beautiful, and supplies all of Europe'. ${ }^{16}$

So one way to ensure Vesuvius's place in the grand narrative of geology was through a process of dispersal: to distribute samples of the volcano to schools, cabinets, academies, universities and laboratories. Monticelli was big in the rock business. Visitors to his collection were given samples, but Monticelli, either for a fee or as part of a system of gift exchange, also distributed larger collections of minerals all over the world. Quite often he was solicited for samples, often in return for election to an academy or in response to a gift of samples from other geological sites. Thus Charles Frederic Bachmann, the Director of the Jena Mineralogy Society, accompanied news that they had awarded Monticelli with a diploma with a request for specimens of Vesuvian rocks. ${ }^{17}$ Monticelli received minerals from Northern Europe: Copenhagen, Stockholm, Norway, southern England, the lower Rhine, Bohemia and Geneva. Others sent materials from the Mediterranean - Marseilles, Trieste, Udine, Catania, and Malta - and from the new world - Mexico, New England and Baltimore. Monticelli himself supplied minerals not just to London, Paris and Copenhagen, but to Jena, Dresden, Marseilles, Turin, Philadelphia, Middlebury Vermont, Washington and Rio de Janeiro, as well as to many Italian museums and collections.

The circulation of these material objects worked through a network of exchange and information (letters, offprints and books) that included more than one hundred and fifty correspondents in Germany (Berlin, Jena, Gottingen, Freiburg, Dresden, Heidelberg and Bonn), London (the British Museum, the Royal Society and the Geological Society), Paris (the Académie des Sciences, the Jardin des Plantes, École des Mines, Musée d'histoire naturelle, and the Institut Historique), Scandinavia (Copenhagen, Helsingfors, Uppsala, Stockholm), Russia (St. Petersburg), as well as in the New World in Vermont, New York, Washington (the National Institute for the Promotion of Science), Buenos Aires, Rio di Janeiro, and Mexico City.

Some of these transactions were at the behest of rulers, diplomats and government officials, others were often facilitated by diplomatic staff who arranged to shepherd valuable specimens through ports and customs. Some were simple commercial transactions with mineral and rock dealers in London, Freiberg, Gottingen, Heidelberg and Vienna. But most of Monticelli's transactions were either with Academies and Museums, or, on a much smaller scale, with private individuals, often in response to gifts - as small as a single rock - or to direct requests for a few specimens. Many grew out of contacts first made in Naples.

The entire range of such exchanges, small and large, personal and official, can be followed in the on-going development of the relationship between Humphry Davy and Monticelli. In February 1816 Davy sent some Cornish minerals to the Abate because, as he wrote to his mother, when he had been in Naples, Monticelli had been 'excessively civil' to me and 'gave me a very fine collection of minerals from Vesuvius'. ${ }^{18}$ Three years later, when Davy returned to Naples, Monticelli gave him 'a list of substances wanting for his collection', and Davy wrote to Faraday in London asking him to arrange a reciprocal gift, which he would pay for ${ }^{19}$ Monticelli had already put together another 'magnificent collection' for Davy, which the Cornishman asked the Abate 'to send to the Royal Institution', suggesting that if they had any duplicates that were on Monticelli's wish list they should give him them in exchange. ${ }^{20}$ Back in London in the autumn of 1820, and newly appointed as the President of the Royal Society, Davy received from Naples two cases of minerals, samples of sea salt, and

\footnotetext{
${ }^{16}$ Private Diary of the Duke of Buckingham, II, p. 38.

${ }^{17}$ Monticelli Mss B.03 Charles Frederic Bachmann to M, n.d. 1832.

18 LHD Humphry Davy to Grace Davy, 14 September 1814.

19 LHD Humphry Davy to Michael Faraday, 3 April 1819.

20 Ibidem.
} 
several bottles of wine. Davy, on his part, told Monticelli that he was waiting for a means of safe passage before sending him a number of precious stones from Ceylon, which were later brought to Naples by William Hamilton, the British envoy. ${ }^{21}$

The scale of these exchanges changed radically in June 1821 when Davy first proposed that the British Museum buy Monticelli's entire Vesuvian collection. ${ }^{22}$ As he made clear from the outset, they were only interested in his volcanic specimens, not in his collection as a whole. By the following spring Davy had Treasury approval to pay E500 for the collection - he had consulted Henry Fitton Secretary of the Geological Society and Lord Compton on the fairness of the price - and designated Compton, who was then resident in Rome, to ensure that the right rocks reached London. ${ }^{23}$ (Back in the summer of 1819 Compton, then in England, had received a shipment of minerals from Monticelli, and had reciprocated with a gift of British specimens). ${ }^{24}$ After some negotiation - Monticelli persuaded the British government to pay for the packing and shipping - the deal went through, and the collection arrived in London some time in 1823.

Monticelli was an exceptionally amenable and hospitable colleague, who went out of his way to help the many foreign visitors who came through Italy in pursuit of learning, aiding, as we have seen, not just geologists and mineralogists, but those interested in archeology and antiquity, agriculture and economics, literature and art. In this respect he was little different from the many savants within Italy, all of whom were Monticelli's correspondents and who acted as hosts to an itinerant army of international savants: Scipione Breislak (1750-1826) and Giovanni Battista Brocchi (1772-1826) in Milan; Stefano Borson (1758-1832) in Turin; Niccolo Da Rio (1765-1845) in Padua; Camillo Ranzani (1775-1841) in Bologna; Fillipo Nesti (1780-1849) in Florence; Luigi Canali (1759-1841) in Perugia; Marco Antonio Fabroni (1782-1845) in Arezzo; Ranieri Gerbi (1763-1839) and Paolo Savi (1798-1871) in Pisa; Carlo Giuseppe Gismondi (1769-1824) and his assistant Pietro Carpi (1792-1861) in Rome; the brothers Mario (1773-1839) and Carlo Gemmellaro (1787-1845) in Catania; and Franceso Ferrara (1767-1850) first in Catania and then in Palermo - all of them shared many of the qualities and characteristics of Monticelli. Most of them combined a university professorship with the custody and nurturing of local natural history collections. Borson became professor of the Sardinian mining school at Moutier after teaching mineralogy at the University of Turin. His massive catalogue of the Turin collections, almost entirely his own work, included 9866 specimens: 6027 minerals, 1486 rocks, 748 marbles and pietre dure, and 1605 fossils. Nesti taught and curated the zoological and mineralogical collections in the Museo di fisica e storia naturale in Florence, which he proudly showed Georges Cuvier when the latter visited in 1809. Similarly, Paolo Savi was professor of Geology, Canali Professor of Physics and Chemistry and Gismondi Professor of Mineralogy; all three presided over important local collections. Gismondi oversaw two in Rome, one at the university, the other at the Collegio Nazzarino. Nearly all of these savants were polymaths: Carlo Gemmellaro was a literary figure and an expert on coins and archaeology; Ferrara was a Professor of Physics, who wrote extensively about archaeology, history, natural history and antiquities. Canali in Perugia collected meteorological observations and built an observatory; Gerbi studied astronomy, physics, insect life, hydraulic systems and published poetry. He was President at the first general meeting of Italian scientists held in Pisa in 1839.

\footnotetext{
21 LHD Humphry Davy to Monticelli, 22 October 1820.

22 Ivi, 20 June 1821.

23 Ivi, 23 April 1822; Davy to Lord Compton, November 1822.

${ }^{24}$ Monticelli Mss C148. Compton to Monticelli n.d; Monticelli Mss D200, 201, 203 Margaret Douglas Maclean Clephane to Monticelli, 19 June 1818; 17 June 1819; 10 August 1821.
} 
This network developed in the first three decades of the nineteenth century. Gismondi who had been Monticelli's teacher in Rome at the turn of the century had first inspired the Abate's interest in minerals and geology, and remained a close friend until his death in 1824. He even moved to Naples for a year in 1816 to help reorganize Monticelli's collections. Canali in Perugia first contacted Monticelli in 1817, after he had read about him in a periodical article; similarly Fabroni in Arezzo wrote to Monticelli in 1823 requesting Vesuvian minerals after reading a paper in a French journal by the famous chemist Joseph Louis Gay-Lussac that praised the Neapolitan's work. ${ }^{25}$ The savants set up mineral exchanges with Monticelli, sending him samples of rocks that he had requested from all over Italy in return for Vesuvian minerals, crystals and lavas. The exchange with Nesti in Florence began in 1811, with Ranzani in Bologna in 1820, Fabroni in Arezzo and Da Rio in Padua in 1824, and with the Gemmellaros in Catania in $1825 .{ }^{26}$ The links in the network were consolidated not just by an exchange of local specimens, but by the mutual distribution of books, pamphlets and periodicals and the proceedings of the various local academies. There was an economy of prestige in which savants in the different cities arranged for the election of their counterparts to be corresponding members of their institutions, which also entitled them to copies of the academies' proceedings.

In certain respects these geologists and mineralogists were resolutely local. The ambit of their researches and publications was largely confined to their immediate surroundings (the major exceptions were Breislak and Brocchi). Gismondi was a figure of enormous stature but only ever published a single article, on the subject of minerals in the vicinity of Rome. Borson travelled extensively in France, but limited his publications to studies of Piedmont. Even a well-travelled savant, like Carlo Gemmellaro, who served as a surgeon in the British army and navy and who attended Humphry Davy's lectures on geology at the Royal Institution in London, focused his attentions on Sicily and Catania. As Pietro Corsi has pointed out, the object of such studies was to feed local information - observations and collections - into some of the larger scientific issues, while retaining a strong sense of place. ${ }^{27}$

But this did not preclude a strong sense that what the savants were producing was "Italian" science. When Luigi Canali wrote to Monticelli from Perugia asking for Vesuvian materials, he justified his request by arguing that he needed 'le cose italiane' to teach his students 'Italian' science. After reading in a foreign journal about a new discovery of Monticelli's collaborator, Nicola Covelli, Nicola Da Rio complained '[w]hat a disappointing thing that one must discover from a French journal what is happening in Italy'. ${ }^{28}$ Pietro Carpi and the famous Professor of Medicine from Pavia, Antonio Scarpa, praised Covelli and Monticelli's Prodromo di Vesuvio as a triumph for Italian science. ${ }^{29}$ Giacinto Cavena, a member of the Academy of Sciences in Turin wanted to procure 'a free and easy scientific and literary communication among the diverse parts of our Italy'.$^{30}$ This was the only means by which the larger picture of Italian geology could be constructed. A number of the group's savants, notably Savi and Gerbi, were important advocates for the first national meeting of Italian scientists, which 421 scholars attended in Pisa in 1839.

This sense of "Italy" was both political and experiential. The generation of savants born between the 1750s and 1770s were well travelled within the Italian

\footnotetext{
${ }^{25}$ Monticelli Mss C.10 Luigi Canali to M 1 August 1817; F01 Antonio Fabroni to M, 4 November 1823.

${ }^{26}$ Monticelli Mss N.04 Filippo Nesti to M, 14 August 1811; D.01, Niccolo Da Rio to M, 16 May 1823.

27 P. Corsi, 'Gemellaro, Carlo', Dizionario Biografico degli italiani, 53 (2000), http://www.treccani.it/ enciclopedia/carlo-gemmellaro_(Dizionario-Biografico) (accessed 1 July 2018).

${ }^{28}$ Monticelli Mss D07. Nicola Da Rio to M, 17 May 1820.

${ }^{29}$ Monticelli Mss C49 Pietro Carpi to M, 1 October 1825.

${ }^{30}$ Monticelli Mss A28. Giacinto Cavana to M, 16 December 1829.
} 
peninsula and had lived under a variety of regimes, many of which aspired, under French rule, to a sort of Italian nationhood. Take the geologist of that generation with the highest international profile, Scipione Breislak. Breislak began his studies in Rome, moved to Nola and Naples where, as an expert in mining and nitre, he was attached to the royal military academy, carrying out extensive researches throughout the Kingdom of Naples. Though a royal employee, his politics were republican and in 1798 he moved back to his native city to serve as the Roman Republic's Minister of Finance. With the collapse of the Republic in 1799 he was forced into political exile, fleeing to Paris, where he worked with such savants as George Cuvier and Alexandre Brongniart. In 1802 he returned to Milan where he was appointed by the government of the Italian Republic as the inspector of the manufacture of powders and saltpetre, a position that enabled him to continue his geological researches. He published works on the lithography and geology of the Campania, Rome, and the province of Milan, and his work was translated into French and German. ${ }^{31}$ He persistently urged Monticelli to publish his work in journals that were available outside Italy in order to promote Italian geological science. ${ }^{32}$ Figures like Breislak demonstrate how often the network of geologists and the network of promoters of Italian political reform overlapped.

Of course Breislak had exceptionally good connections outside Italy, especially in Paris. But the most important figures in making international connections for the Italian savants were two outsiders with loose ties to the network, namely the young Irishman Joseph Barclay Pentland (1797-1873), who for many years was Cuvier's intermediary in his dealings with both Britain and Italy, and the Genevan watch manufacturer, amateur botanist and geologist Moise-Etienne Stefano Moricand (17791854). ${ }^{33}$ Their range of contacts among the savants was greater than that of the Italians, and they were far more assiduous in getting the group to work together. Pentland, though he held no official position and had no salary, worked for Cuvier in the Jardin des Plantes, collaborating closely with Buckland in Oxford, ${ }^{34}$ with London's Royal Society, and with many savants on the Italian peninsula. He was an exceptionally energetic and ebullient character, who bombarded the much more phlegmatic Monticelli with schemes and ideas. After a first Italian trip in early 1822 (before the major eruption of Vesuvius in October-November 1822) Pentland set up an exchange between Cuvier and Monticelli, giving the latter detailed instructions about what Paris needed. He encouraged links with Nesti in Florence and an exchange between Monticelli and Vitaliano Borromeo Arese, a Milanese who had acquired Breislak's geological collection. He got Monticelli to coordinate a southern Italian search for specimens of sea turtles and medusa that Cuvier wanted for his researches (Gemmellaro was able to provide the turtles), as well as to organize a hunt for porpoise fossils. In return he bombarded Monticelli with gifts - French fossils and minerals, copies of works by Alexander von Humboldt and Cuvier, proceedings of the French academies, and a series of models of fossils, approved by Cuvier, which were intended to help Italian researchers identify the materials that they found. He even arranged with a French and a London dealer in scientific instruments that Monticelli could purchase equipment he needed in exchange for supplying them with Vesuvian lavas and crystals. At the same time he urged Monticelli to broaden the scope of his work -

\footnotetext{
${ }^{31}$ L. Gennari, 'Breislak, Scipione', Dizionario Biografico degli italiani, 14 (1972), http://www.treccani.it/ enciclopedia/scipione-breislak_(Dizionario-Biografico) (accessed 29 June 2018).

32 Monticelli Mss B.67 Scipione Breislak to M, 29 April 1819.

${ }^{33}$ For the importance of loose ties in making networks see the classic article, M.S. Granovetter, 'The strength of weak ties', in: American Journal of Sociology, 78 (1973), pp. 1360-1380.

${ }^{34}$ For which see W.A.S. Sarjeant \& J.B. Delair, 'An Irish Naturalist in Cuvier's laboratory: the letters of Joseph Pentland, 1820-1822', in: Bulletin of the British Museum (Natural History) (historical series), 6 (1980), pp. 245-319.
} 
to extend it beyond Vesuvius to cover the whole of the Neapolitan kingdom and to focus on geology rather than mineralogy. ${ }^{35}$

The Swiss Moise-Etienne Stefano Moricand, born in Geneva, had spent the years of his youth in Italy in the watch and clock trade. ${ }^{36}$ As a young man he had become fascinated with gems and crystals, and when he returned to Geneva he began to study them, and to support the natural history museum that was established in 1818 . He continued to make frequent trips to Italy (he visited Monticelli in 1815 and 1819), and was a good friend of Breislak, Gismondi, and Brocchi, writing gossipy letters about their researches and travels. Between 1816 and 1819 he published three short papers on lavas and crystals in the Bibliotheque Universelle, the widely-read Genevan periodical edited by Marc-Auguste Pictet, which were heavily indebted to Monticelli. But, though concerned to establish his scholarly credentials (about which he was always anxious), and though an enthusiastic mineralogist and botanist, Moricand was also an important dealer who sold minerals and offered his services to savants. He had contacts in Germany, Russia and the New World as well as France. In 1817 he introduced Ernst Odeleben, the German dealer who sold minerals to Goethe, to Monticelli, who also bought specimens from him. He plied Monticelli with information about the prices of crystals in different parts of Europe, sent him boxes of minerals from northern Italy and journals and books from Geneva. In return he solicited specimens for the Geneva museum and strontium sulfate crystals, which he especially valued as their beauty and rarity made them powerful bargaining chips in trading for other minerals. ${ }^{37}$

Pentland linked the Italian geologists to Paris, reinforcing a connection that in some cases went back to the era when the universities of northern and central Italy had been under French control. (Several of the savants knew Cuvier from the time he spent in Italy as Inspector General of the Imperial University in 1809-1810 and 1813.) After Ranzani met Cuvier in Bologna in 1810, he spent fourteen months working in Paris. Moricand, as Breislak knew, was a vital link to the major mineral dealers in northern Europe, while he and his colleagues in Geneva - often referred to as 'the Athens' of Europe - helped propagate Italian science north of the Alps, notably through the journal Bibliothèque Britannique or Bibliothèque Universelle, as it became known after 1815. The first contacts of these outsiders and many other foreign savants with Italian geologists were as travellers, visitors and collectors; their contribution to sciences within Italy were vital as they helped bind the Italians even more closely together and cemented their connections with the scientific community throughout Europe. As Dorinda Outram reminds us, '[i]n natural history, perhaps more than in any other scientific discipline, the exchange of tangible objects or information about them, in the shape of specimens, casts, drawings and verbal descriptions, was of crucial importance in research'. ${ }^{38}$

But maintaining connections, furthering the cause of mineralogy and geology, was not an easy task. Though it had been somewhat easier under the French

\footnotetext{
${ }^{35}$ Monticelli Mss P.26, 27, 30, 32, 34, 35, 37, 38, 40, 42, 48, 49, Pentland to M., 22 August, 3 October 1822, n.d., 24 August, 22 November 1823, 23 February, 24 June, 24 July, 22 October 1824, 26 September 1829, 15 October 1841, 22 May 1843.

${ }^{36}$ For his life see B. Breure \& E. Tardy, 'From the shadows of the past: Moricand senior and junior, two 19th century naturalists from Geneva, their newly described taxa and molluscan types', in: Revue Suisse de zoologie, 123, 1 (2016), pp. 113-138; 'Moricand, Moïse Etienne (Stefano) (1779-1854)', Global Plants, https: / / plants.jstor.org/stable/10.5555/al.ap.person.bm000005815 (accessed 29 June 2018).

${ }^{37}$ Monticelli Mss M. 249-251, 253, 257-8, 260, 262, 266, 268-9, 274-5, Moise-Etienne Stefano Moricand to M, 24 December 1814, 22 September, 22 November 1815; 28 January, 12 May, 14 July, 1816; 3 January, 22 June, 27 July 1817; 8 February, 5 June, 17 July 1818; 14 May, 2 June 1820.

${ }^{38}$ D. Outram, Georges Cuvier. Vocation, science and authority in post-revolutionary France, Manchester, Manchester UP, 1984, p. 84.
} 
occupation, after 1815 it was difficult to generate and spread scientific knowledge through the Italian peninsula and beyond in an autocratic and divided world where censorship, suspicious customs officials, multiple postal systems, spies and poor communications meant that books, specimens and journals were constantly destroyed, damaged, impounded, suppressed or simply lost. In short, communication was expensive and hazardous. In such a situation the traveller, who could carry books, letters and boxes of specimens was vital to the health and strength of intellectual inquiry. Operating with a system of exchange in which the traveller was given letters of recommendation, but was expected in return to perform favours that linked the author and the recipient, Italian savants passed travellers on to one another as they made their way down and back up the peninsula. Nesti in Florence, for example, wrote letters of introduction to Monticelli for Ashurst Majendie, an English member of the geological society, Mr. Saybrot, a naturalist from Philadelphia, Mr. Fowler, an American educated at the École des Mines in Paris who eventually donated his mineral collection to Princeton University, Herr Dietz of Vienna, and Hermann Abish, a geological professor from Estonia. ${ }^{39}$ Monticelli, in turn, was a vital source of letters for savants like Brocchi, Davy, Charles Daubeny, William Buckland and William Frederick Herschel, who wanted to visit and meet geologists and astronomers in Messina, Palermo and Catania. ${ }^{40}$

Many of these travellers, armed with letters of recommendation, were asked to convey parcels and packages. During his tour in Europe in 1819-1820 the New York mineralogist and politician, Stephen Van Rensselaer (1764-1838) brought Monticelli two books on crystals from Paris, that he had been given by their author, Brochant de Villiers, a geologist at the Écoles des Mines. ${ }^{41}$ A year later the Swedish mining engineer, Eric Thomas Svedenstierna, who had a sideline in selling minerals, had a young army officer posted to Naples bring Monticelli twenty specimens of Swedish and Russian rocks from Stockholm. ${ }^{42}$ When Moricant first approached Monticelli he sent a small deposit of rare lava via Joseph Liboschitz, the Lithuanian doctor, composer and naturalist, who was Czar Alexander I's personal physician. ${ }^{43}$ Liboschitz had journeyed from St. Petersburg, via Geneva to Naples. Camillo Ranzani in Bologna persuaded the pharmacist and botanist Antonio Orsini from Ascoli to carry a volume of scientific pamphlets and two volumes of his small elementary work on zoology to Naples. ${ }^{44}$ Just as erudite travellers brought him books, rocks and crystals, so Monticelli used his visitors to convey books and pamphlets. The English astronomer John William Frederick Herschel took copies of Monticelli's Prodromo di Vesuvio to his friends in Catania. ${ }^{45}$ Scipione Breislak received materials in Milan through a Milanese aristocrat, Count Porro, who had been visiting Naples, and via the Crown Prince of Denmark, who was eager to meet him after his visit to Vesuvius in $1820 .{ }^{46}$ There were, of course, other means by which scientific knowledge circulated, but most, as the savants often found to their cost, were deeply uncertain. Friends, beholden and sympathetic made the best couriers; only a diplomat, who enjoyed immunity from inspection and search, was better.

\footnotetext{
${ }^{39}$ Monticelli Mss N.06, 08, 09, 11, 12, Nesti to M, 25 September 1818, 18 October 1819, 9 September 1827, 30 April 1833, 18 September 1833.

40 Monticelli Mss. B.85 Brocchi to M, 2 May 1819; B.108 William Buckland to M.,n.d.; F.18, 20, Francesco Ferrara to M, 26 July 1824, 1 June 1826; G. 23, Mario Gemmellaro to Monticelli 20 June 1824.

${ }^{41}$ Monticelli Mss. V14 Stephen Van Rensselaer to M, n.d. 1819.

42 Monticelli Mss S.161 Eric Thomas Svedenstierna to M, 1 June 1820.

43 Monticelli Mss M.249 Moricand to M. 24 December 1814

${ }^{44}$ Monticelli Mss R.03 Camillo Ranzani to M, 7 May 1820.

45 Monticelli Mss M.40 Carmelo Maramigna to M, 4 July 1824.

${ }^{46}$ Monticelli Mss B.63, 71, Scipione Breislak to M, 26 February 1817, 16 June 1821.
} 
Though there was a strong ethos of collaboration between the travellers and the Italian savants, we should not be too panglossian about these relationships. As he travelled through Italy in 1828-1829, the Duke of Buckingham was often critical of the collections he visited and the savants he talked to. After dining with Professor Borelli, a mineralogist at the University of Turin who worked closely with Borson, Buckingham expostulated, '[i]t is extraordinary how ignorant these philosophers are of everything out of the immediate range of their pursuits. Many of the most interesting localities Borelli did not even know by name'. Similarly he was dissatisfied with the mineral collection 'arranged after the system of Brongniart, by Mr Borson', complaining that '[i]ts collection of volcanic materials is paltry, and not separated from the rest' ${ }^{47}$ (After Buckingham's departure Borson promptly wrote to Monticelli, asking him for specimens from Vesuvius).$^{48}$ At Naples Buckingham's complaints also focused on the local nature of the collections. After praising Monticelli's Vesuvian collection, he grumbled that ' $[\mathrm{h}]$ is general collection is meager and bad' ${ }^{49}$ Local strength was parsed by Buckingham as a general weakness.

Conversely, the Italian savants, though they desperately wanted foreign visitors to draw on their local expertise, often felt a certain superiority towards them, because their guests were bound to be less knowledgeable of local conditions. In Catania Gemmellaro used his local knowledge to jealously guard his intellectual independence. In the 1820s a number of Neapolitan intellectuals mounted a campaign to dispel what they saw as the often superficial and frequently misinformed foreign misapprehensions about both the volcano and the kingdom that surrounded it. Someone like Leopoldo Pilla, a protégé of Monticelli's (though they were to fall out later), who became Professor of Geology at Pisa, and who died on the battlefield fighting for the revolution in 1848, started a series of publications, Le Spettatore del Vesuvio, designed to reveal the scientific value of Vesuvius to foreigners, whose visits, he argued, were too brief, too superficial, and too dependent on other accounts to be properly informed. He was particularly disparaging of the very successful guide written by the Canadian geologist and alpinist John Auldjo, the Sketches of Vesuvius, published in Naples and London in both English and French. ${ }^{50}$ In 1827 Gabriele Quattromani produced the Itinerario delle due Sicilie (also published in a French edition), as the first 'Mappa Statistica' of the Two Kingdoms with the overt object of rebutting most foreign accounts which he dismissed as 'romanzi' ('novels'). ${ }^{51}$ Much of the data the Itinerario contained came from reports of commissions on the Neapolitan infrastructure to which Monticelli had contributed. This concern with the outsider's point of view was persistent: the argument for the publication of Monticelli's various papers into two volumes of collected works in 1844 was that it would increase their visibility among foreigners.

This was all the more important after 1815 because of the delicate position that science and new knowledge occupied in the world of Restoration absolutism. Under the French, Neapolitan savants like Monticelli had assumed positions of power, quite often taken administrative office and promoted legal and educational reform (though with mixed success). The revival of the Royal Academies, including that of science, the establishment of new chairs in the University, the foundation of the Academia Pontaniana, a body of the great and the good, and the promotion of the Istituto d'Incoraggiamento, which had as its explicit purpose the application of the sciences of mathematics, physics, chemistry, and economics to government administration and to

\footnotetext{
47 Private Diary of the Duke of Buckingham, II, pp. 264-265.

48 Monticelli Mss B.61 Stefano Borson to M., n.d.

49 Private Diary of the Duke of Buckingham, II, p. 38.

$50 \mathrm{~J}$. Auldjo, Le Spettatore del Vesuvio e de' Campi Flegrei. Giornale compilato dai Sigg. F Cassola \& E.L. Pilla, Napoli, Torchi del Tramater, 1832-1833, pp. 4, 34.

${ }^{51} \mathrm{G}$. Quattromani, Itinerario delle due Sicilie, Napoli, Dalla Stamperia Francese, 1827, p. 219.
} 
the economy, especially agriculture: all this helped shape a reformist agenda that drew in Neapolitans, even when they were unhappy about French interference, and about the terrible economic burden placed on the Kingdom by its obligations to pay for French armies. These institutions also helped shape an elite in the French manner, a body of administrators, technocrats and scientists, of which Monticelli was an important member. In particular there was a large overlap between the membership of the Academy of Sciences, the Academia Pontaniana, and the Istituto d'Incoraggiamento. ${ }^{52}$ Monticelli, Vincenzo Cuoco, and Melchiorre Delfico were members of all three.

But this positive, reformist environment and its proponents, though it survived the Restoration, came under suspicion from the Crown and the Church. Neapolitan monarchs, like their counterparts elsewhere in Europe, were eager to win the international prestige that came with the support and development of science and technological innovation. Certainly, the Bourbons were not hostile to new technologies. Naples, after all, had the first steamship service and the first railway in Italy. (It also had some state of the art panopticon prisons). But the rulers wanted, like the panopticon, to exercise surveillance and control; they were terrified of unleashing the forces of reform and of liberalism, especially those that might produce political change. The position of Italian savants - and not just those in Naples - remained fragile. A great many, though not all, were in favour of political reform, some were ardent revolutionaries; all saw the necessity of exchanging and circulating knowledge and information if the sciences of the earth were to develop and grow, and were mindful of the many obstacles they faced in the politically fractured but broadly reactionary regimes of the peninsula. The stratagem of building connections, of creating networks was something that was not confined to Italian nineteenth-century scholars and scientists; it was a general scientific practice. But the particular circumstances of Italy before Unification made the networking doubly valuable, as a refuge for the like-minded as well as a vehicle for the dissemination of knowledge.

\section{Keywords}

Geology, Networks, Naples, Vesuvius, Monticelli

John Brewer is Faculty Associate in the Harvard University History Department and Eli and Edythe Broad Emeritus Professor in Humanities and Social Sciences at the California Institute of Technology in Pasadena, California. His many books include The Sinews of Power: War, Money and the English State (1989); The Pleasures of the Imagination: English Culture in the Eighteenth Century (1996); and The American Leonardo: a 20th century tale of obsession, art and money (2009). He is currently engaged in a project on Naples, Vesuvius and the Buried Cities in the age of Romanticism.

Harvard University / California Institute of Technology

58 Tahanto Trail

Harvard (MA) 01451 (USA)

jbcaltech@yahoo.com

\footnotetext{
52 For these institutions see A. Lepore, 'Il dibattito economico negli atti dell'Accademia delle scienze, sezione della Società Reale Borbonica (1817-1861)'; L. Alessandro, 'L’Accademia Pontanina di Napoli nell'Ottocento'; and F. Di Battista, 'Origini e involuzione dell'Istituto di Incoraggiamento di Napoli', in: M.M. Augello \& M.E.L. Guidi (eds.), Associazionismo economico e diffusione dell'economia politica nell'Italia dell'Ottocento : dalle società economico-agrarie alle associazioni di economisti, Milano, FrancoAngeli, 2000, pp. 201-232, 233-260, 261-274.
} 


\section{RIASSUNTO \\ Reti scientifiche, il Vesuvio e la politica: il caso di Teodoro Monticelli a Napoli, 1790-1845}

Questo articolo indaga le attività e l'uso di reti di studiosi da parte di Teodoro Monticelli, il geologo, funzionario e segretario dell'Accademia scientifica di Napoli all'inizio del XIX secolo. L'autore pone in evidenza come Monticelli costruì una rete di connessioni con i suoi colleghi studiosi e geologi in tutta la penisola italiana, che, allo stesso tempo, era collegata a una rete internazionale di studiosi, centrata principalmente su Parigi, ma che si estendeva alla Russia e al Nuovo Mondo. Tali reti venivano sostenute attraverso lo scambio di informazioni per corrispondenza e la condivisione di pubblicazioni, e attraverso il dono, il baratto, lo scambio e la vendita di esemplari geologici. Grazie alla mediazione di viaggiatori, alcuni italiani, più spesso stranieri, ostacoli come le cattive comunicazioni e la censura furono superati: la loro funzione era di trasportare lettere, pubblicazioni ed esemplari geologici tra i diversi centri in cambio di raccomandazioni che consentivono loro accesso a studiosi, collezioni, università e accademie. In particolare, la rete all'interno della penisola italiana cercò consapevolmente di sviluppare una scienza "italiana". A Napoli Monticelli usò il fascino scientifico del Vesuvio e il suo speciale ruolo di principale esperto locale per promuovere le riforme all'interno del Regno delle Due Sicilie e per realizzare la sua visione di Napoli come centro di indagine scientifica. 